\title{
Pengaruh variasi kecepatan udara dan massa bahan terhadap waktu pengeringan jagung pada alat fluidized bed
}

\author{
S. Syahrul*, R. Romdhani, M. Mirmanto \\ Teknik Mesin, Fakultas Teknik, Universitas Mataram, Jl. Majapahit no. 62 Mataram, NTB. \\ *E-mail : syahrul_husain@yahoo.com
}

\section{ARTICLE INFO \\ Article History: \\ Received 14 September 2016 \\ Accepted 22 October 2016 \\ Available online 30 December 2016}

\section{Keywords:}

Maize

Fluidization

Fluidized bed

Air velocity

Mass of material

\begin{abstract}
Indonesia is an agricultural country that has many agricultural products so that post-harvest handling is necessary so that the crop is not quickly broken when stored or distributed. One harvests in Indonesia, which require post-harvest handling such as corn. Based on $\mathrm{SNI}$, the maximum moisture content of corn feed raw material has a moisture content of $14 \%$. The water content of the corn used is $20 \%$ with a tolerance of \pm $0.5 \%$. Variations air speed used is $5 \mathrm{~m} / \mathrm{s}, 6 \mathrm{~m} / \mathrm{s}$ and 7 $\mathrm{m} / \mathrm{s}$ with a variation of the mass of material that is 0.5 $\mathrm{kg}, 1 \mathrm{~kg}$, and $1.5 \mathrm{~kg}$. With the variation of air velocity and mass of the material showed that the higher the speed of the air, the faster drying time. In addition, the heavier material is drained, it will take longer. Variations of air velocity and mass of materials that require the fastest drying time is the air speed of $7 \mathrm{~m} / \mathrm{s}$ with a mass of $0.5 \mathrm{~kg}$. Variations of air velocity and mass of material that takes the longest drying air is at a speed of $5 \mathrm{~m} / \mathrm{s}$ with a mass of $1.5 \mathrm{~kg}$ of material.
\end{abstract}

\section{PENDAHULUAN}

Indonesia merupakan negara agraris karena sebagian besar penduduknya bermatapencaharian sebagai petani. Selain itu juga, Indonesia dikatakan negara agraris karena memiliki luas daratan sepertiga dari luas keseluruhan wilayahnya. Oleh karena itu, lahan pertanian Indonesia sangat luas dan hasil pertaniannya berlimpah dan beragam. Dengan kondisi hasil pertanian yang berlimpah dan beragam tersebut dibutuhkan penanganan pasca panen yang tepat agar hasil panen awet dan tidak cepat rusak ketika disimpan atau didistribusikan ke masyarakat. Salah satu cara yang dilakukan petani menangani hasil panen yaitu dengan cara pengeringan. Pengeringan bertujuan untuk mengurangi kadar air yang tersimpan di dalam bahan.

Indonesia yang beriklim tropis memiliki dua musim, yaitu musim penghujan dan musim kemarau. Musim kemarau merupakan musim yang dimanfaatkan oleh petani terutama untuk proses pengeringan hasil panen. Petani biasanya mengeringkan hasil panen dengan cara konvensional, yaitu pengeringan yang membutuhkan panas matahari. Pengeringan konvensional sangat bergantung pada musim, membutuhkan lahan luas, dan waktu yang lama. Pada musim penghujan, proses pengeringan terhambat disebabkan intensitas cahaya matahari sangat sedikit sehingga kualitas hasil panen bisa menurun dan rusak. Hasil panen yang rusak membuat para petani merugi karena 
harga jualnya lebih murah dibandingkan dengan kualitas hasil panen yang kering dan bermutu baik.

Hasil panen yang membutuhkan pengeringan pasca panen salah satu diantaranya yaitu jagung. Jagung adalah penghasil karbohidrat yang bisa dijadikan makanan pokok seperti beberapa daerah di Indonesia. Maka dari itu, pengeringan jagung pasca panen sangat dibutuhkan untuk keawetannya selama disimpan ataupun didistribusikan. Tingkat keawetan jagung ditentukan dari jumlah kadar air yang tersimpan di dalamnya. Kadar air berlebihan yang tersimpan di dalam biji jagung bisa menyebabkan kerusakan karena aktivitas mikroba, bakteri, dan jamur. Berdasarkan SNI.01-4483-1998, persyaratan mutu standar jagung bahan baku pakan memiliki kadar air 14\% (Departemen pertanian, 1998). Untuk mengatasi kendala pengeringan konvensional dan mendapatkan kualitas hasil pasca panen yang cepat dan baik, dapat diterapkan teknologi tepat guna yaitu fluidisasi. Fluidisasi adalah metode pengontakan butiran-butiran padat dengan fluida baik cair maupun gas. Dengan metode ini diharapkan butiran-butiran padat memiliki sifat seperti fluida dengan viskositas tinggi. Ketika laju aliran kemudian dinaikkan, akan sampai pada suatu keadaan dimana unggun padatan akan tersuspensi di dalam aliran gas yang melaluinya. Pada keadaan ini masing-masing butiran akan terpisahkan satu sama lain sehingga dapat bergerak dengan lebih mudah. Pada kondisi butiran yang dapat bergerak ini, sifat unggun akan menyerupai cairan dengan viskositas tinggi, misalnya adanya kecenderungan untuk mengalir, mempunyai sifat hidrostatik dan sebagainya. Fluidisasi tersebut sangat dipengaruhi oleh faktor-faktor antara lain: laju alir fluida, jenis fluida, ukuran partikel, bentuk partikel, jenis dan densitas partikel, faktor interlock antar partikel, porositas unggun, distribusi aliran, distribusi bentuk ukuran partikel, serta diameter kolom (Ardani dkk, 2013). Fenomena yang terjadi manakala laju alir masih cukup rendah adalah butiran padat dalam kolom tetap diam karena fluida hanya mengalir melalui ruang antar partikel tanpa menyebabkan perubahan susunan partikel tersebut. Pada saat kecepatan aliran fluida diperbesar sehingga mencapai kecepatan minimum, yaitu kecepatan saat gaya seret fluida terhadap partikel-partikel padatan lebih atau sama dengan gaya berat partikel-partikel padatan tersebut, partikel yang semula diam akan mulai terekspansi (Widayati, 2010). Semakin banyak berat umpan maka penurunan kandungan uap air di padatan akan semakin landai. Hal ini disebabkan dengan semakin banyak bahan yang akan dikeringkan, maka kebutuhan energi panas untuk mengeringkan akan semakin besar (Suherman dkk, 2012). Hasil penelitian Hargono dkk (2012), terhadap karakterisasi proses pengeringan jagung dengan metode mixed-adsorption drying menggunakan zeolit pada unggun terfluidisasi memperlihatkan bahwa laju pengeringan paling cepat ditandai oleh penurunan kadar air yang paling besar yang terjadi pada suhu $50^{\circ} \mathrm{C}$.

\section{Tujuan Penelitian}

1. Untuk mengetahui pengaruh variasi kecepatan udara dan massa bahan terhadap waktu pengeringan jagung pada alat fluidized bed.

2. Untuk mengetahui waktu tercepat dalam pengeringan jagung pada alat fluidized bed dengan memvariasikan kecepatan udara dan massa bahan.

3. Untuk mengetahui efisiensi pengeringan dengan memvariasikan kecepatan udara dan massa bahan.

\section{Proses Pengeringan}

Bahasa ilmiah pengeringan adalah penghidratan, yang berarti menghilangkan air dari suatu bahan. Proses pengeringan atau penghidratan berlaku apabila bahan yang dikeringkan kehilangan sebahagian atau keseluruhan air yang dikandungnya. Proses utama yang terjadi pada proses pengeringan adalah penguapan. Penguapan terjadi apabila air yang dikandung oleh suatu bahan teruap, yaitu apabila panas diberikan kepada bahan tersebut. Panas ini dapat diberikan melalui berbagai sumber seperti kayu api, minyak dan gas, dan arang baru ataupun tenaga surya.

Pengeringan juga dapat berlangsung dengan cara lain yaitu dengan memecahkan ikatan molekul-molekul air yang terdapat di dalam bahan. Apabila ikatan molekul-molekul air yang terdiri dari unsur dasar oksigen dan hidrogen dipecahkan, maka molekul tersebut akan keluar dari bahan. Akibatnya bahan tersebut akan kehilangan air yang dikandungnya.

Cara ini juga disebut pengeringan atau penghidratan. Untuk memecahkan ikatan oksigen dan hidrogen ini biasanya digunakan gelombang mikro. Gelombang mikro merambat dengan frekuensi yang tinggi. Apabila gelombang mikro disesuaikan setara dengan getaran molekulmolekul air maka akan terjadi resonansi yaitu ikatan molekul-molekul oksigen dan hidrogen digetarkan dengan kuat pada frekuensi gelombang mikro yang diberikan sehingga ikatannya pecah (Hasibuan, 2005). 
Proses pengeringan merupakan proses perpindahan panas dari sebuah permukaan benda sehingga kandungan air pada permukaan benda berkurang. Perpindahan panas dapat terjadi karena adanya perbedaan temperatur yang signifikan antara dua permukaan. Perbedaan temperatur ini ditimbulkan oleh adanya aliran udara panas di atas permukaan benda yang akan dikeringkan yang mempunyai temperatur lebih dingin.

Aliran udara panas merupakan fluida kerja bagi sistim pengeringan. Komponen aliran udara yang mempengaruhi proses pengeringan adalah kecepatan, temperatur, tekanan, dan kelembaban relatif (Mahadi, 2007). Menurut Daulay (2005), pada proses pengeringan banyak faktor yang perlu diperhatikan seperti iklim dan bahan baku yang mempengaruhi waktu dan perolehan pengeringan. Berdasarkan prosesnya, dikenal dua macam pengeringan yaitu pengeringan secara alami dan secara mekanis. Pengeringan fluidisasi dapat digunakan untuk mengatasi kelemahan dari cara dan alat pengering yang ada. Pengering fluidisasi mempunyai beberapa kelebihan yaitu laju perpindahan panas dan massa cukup tinggi karena kontak antara udara panas pengering dengan bahan yang dikeringkan cukup baik, temperatur dan kadar air seragam, kontruksi sederhana, dan kapasitas pengering tinggi (Yahya, 2015).

\section{Macam-macam Pengeringan \\ 1. Pengeringan dengan cara alami}

Dalam sektor pertanian sistem pengeringan yang umum digunakan adalah tenaga surya. Pada sistem tenaga surya ini, bahan diekspos ke sinar surya secara langsung maupun tidak langsung. Uap air yang terjadi dipindahkan dari tempat pengeringan melalui aliran udara. Proses aliran udara ini terjadi karena terdapat perbedaan tekanan. Perbedaan tekanan udara ini dapat terjadi secara konveksi bebas maupun konveksi paksa. Konveksi bebas terjadi tanpa bantuan luar, yaitu pengaliran udara hanya bergantung pada perbedaan tekanan yang disebabkan oleh perbedaan densitas udara. Sedangkan pada konveksi secara paksa digunakan kipas untuk memaksa gerakan udara (Hasibuan, 2005).

Pengeringan bertujuan untuk memperpanjang umur simpan dengan cara mengurangi kadar air untuk mencegah tumbuhnya mikroorganisme pembusuk. Dalam proses pengeringan dilakukan pengaturan terhadap suhu, kelembaban (humidity), dan aliran udara. Perubahan kadar air dalam bahan pangan disebabkan oleh perubahan energi dalam sistem. Untuk itu, dilakukan perhitungan terhadap neraca massa dan neraca energi untuk mencapai keseimbangan

Alasan yang mendukung proses pengeringan dapat menghambat pertumbuhan mikroorganisme adalah untuk mempertahankan mutu produk terhadap perubahan fisik dan kimiawi yang ditentukan oleh perubahan kadar air, mengurangi biaya penyimpanan, pengemasan dan transportasi, untuk mempersiapkan produk kering yang akan dilakukan pada tahap berikutnya, memperpanjang umur simpan dan memperbaiki kegagalan produk. Produk kering dapat digunakan sebagai bahan tambahan dalam pembuatan produk baru.

\section{Pengeringan dengan udara panas}

Secara buatan proses pengeringan dapat dilakukan dengan alat pengering untuk menghemat tenaga manusia, terutama pada musim hujan. Terdapat berbagai cara pengeringan buatan, tetapi prinsipnya sama yaitu untuk mengurangi kadar air di dalam biji dengan panas pengeringan sekitar $38-43^{\circ} \mathrm{C}$ sehingga kadar air turun menjadi 12-13\%. Alat pengering dapat digunakan setiap saat dan dapat dilakukan pengaturan suhu sesuai dengan kadar air biji jagung yang diinginkan. Cara ini lebih baik karena tidak tergantung cuaca dan bahan bakar lebih sedikit. Pengeringan buatan dilakukan selama 32 jam dan pembalikkan biji setiap 3 jam. Lama pengeringan tergantung dari jenis alat pengeringnya. Prinsip pengeringannya menggunakan udara pengering sebagai medium panas dalam menurunkan kadar air biji hingga 911\% (Tanggasari, 2014).

\section{Faktor yang Mempengaruhi Pengeringan}

Faktor-faktor yang mempengaruhi pengeringan ada dua golongan yaitu faktor yang berhubungan dengan udara pengering dan faktor yang berhubungan dengan sifat bahan yang dikeringkan. Faktor-faktor yang termasuk golongan pertama adalah suhu, kecepatan volumetrik aliran udara pengering, dan kelembaban udara. Faktor-faktor yang termasuk golongan kedua adalah ukuran bahan, kadar air awal, dan tekanan parsial di dalam bahan (Tanggasari, 2014).

Kelembaban adalah suatu istilah yang berkenaan dengan kandungan air di dalam udara. Udara dikatakan mempunyai kelembaban yang tinggi apabila uap air yang dikandungnya tinggi, begitu juga sebaliknya. Secara matematis, kelembaban dihubungkan sebagai rasio berat uap air di dalam suatu volume udara, 
dibandingkan dengan berat udara kering (udara tanpa uap air) di dalam volume yang sama.

Komponen yang paling banyak di dalam udara adalah oksigen, nitrogen, dan uap air. Oksigen dan nitrogen tidak mempengaruhi kelembaban udara, sedangkan kandungan uap air sangat berpengaruh terhadap kelembaban udara. Udara yang kurang mengandung uap air dikatakan udara kering, sedangkan udara yang mengandung banyak uap air dikatakan udara lembab.

Keadaan suhu, tekanan, dan kandungan uap air udara dikenal sebagai kualitas udara. Setelah kualitas udara diketahui, barulah kita dapat mengkaji kemampuan udara menguapkan air yang berada dalam suatu bahan, karena bahan yang akan dikeringkan selalu berada di dalam udara berkualitas tertentu. Pengalaman sehari-hari kita dapati bahwa sejumlah udara hanya mampu untuk mengeringkan suatu bahan atau menguapkan air dari suatu bahan apabila bahan tersebut tidak seratus persen lembab. Dengan kata lain, kemampuan udara untuk menguapkan air dalam suatu bahan pada proses pengeringan adalah maksimum apabila udara tersebut kering, dan nol apabila udara tersebut jenuh dengan uap air. Pada keadaan biasa, udara tidak seratus persen kering atau lembab, sehingga udara masih mampu melakukan proses pengeringan apabila bahan-bahan yang mengandung air diletakkan di dalamnya (Hasibuan, 2005).

\section{Fenomena-fenomena Fluidisasi}

Menurut Widayati (2010), fenomenafenomena yang dapat terjadi pada proses fluidisasi antara lain :

1. Fenomena fixed bed yang terjadi ketika laju alir fluida kurang dari laju minimum yang dibutuhkan untuk proses awal fluidisasi. Pada kondisi ini partikel tetap diam.

2. Fenomena minimum or incipient fluidization yang terjadi ketika laju alir fluida mencapai laju alir minimum yang dibutuhkan untuk proses fluidisasi. Pada kondisi ini partikelpartikel padat mulai terekspansi.

3. Fenomena smooth or homogenously fluidization terjadi ketika kecepatan dan distribusi aliran fluida merata, densitas dan distribusi partikel dalam unggun sama atau homogen sehingga ekspansi pada setiap partikel padatan seragam.

4. Fenomena bubbling fluidization yang terjadi ketika gelembung-gelembung pada unggun terbentuk akibat densitas dan distribusi partikel tidak homogen.

5. Fenomena slugging fluidization yang terjadi ketika gelembung-gelembung besar yang mencapai lebar dari diameter kolom terbentuk pada partikel-partikel padat. Pada kondisi ini terjadi penorakan sehingga partikel-partikel padat seperti terangkat.

6. Fenomena chanelling fluidization yang terjadi ketika dalam unggun partikel padatan terbentuk saluran-saluran seperti tabung vertikal.

7. Fenomena disperse fluidization yang terjadi saat kecepatan alir fluida melampui kecepatan maksimum aliran fluida. Pada fenomena ini sebagian partikel akan terbawa aliran fluida.

Sifat dan fenomena fluidisasi tersebut sangat dipengaruhi oleh faktor-faktor : laju alir fluida dan jenis fluida, diameter partikel dan bentuk partikel, jenis dan densitas partikel, porositas unggun, distribusi aliran, bentuk kolom, diameter kolom, dan tinggi unggun.

\section{Analisa Efisiensi Energi Pengeringan}

Menurut Taufiq (2004), efisiensi pengeringan adalah hasil perbandingan antara panas yang secara teoritis dibutuhkan dengan penggunaan panas yang sebenarnya dalam pengeringan.

Jumlah kalor (panas) yang digunakan untuk pengeringan dapat dihitung dengan menggunakan rumus berikut, Taufiq (2004):

$Q=Q_{1}+Q_{2}+Q_{3}$

Dimana $Q$ adalah jumlah panas yang digunakan untuk pengeringan $(\mathrm{kJ}), \mathrm{Q}_{1}$ adalah panas sensibel jagung $(\mathrm{kJ}), \mathrm{Q}_{2}$ adalah Panas sensibel air $(\mathrm{kJ}), \mathrm{Q}_{3}$ adalah panas laten penguapan air (kJ). $Q_{1}$ dapat dinyatakan sebagai: (Hargono dkk., 2012).

$Q_{1}=m_{k} c_{p}\left(T_{p}-T_{i}\right)$

Dimana $Q_{1}$ adalah jumlah panas yang digunakan untuk pengeringan, $\mathrm{m}_{\mathrm{k}}$ adalah assa kering bahan $(\mathrm{kg}), \mathrm{c}_{\mathrm{p}}$ adalah panas jenis bahan $\left(\mathrm{kJ} / \mathrm{kg}^{0} \mathrm{C}\right), \mathrm{T}_{\mathrm{p}}$ adalah suhu akhir jagung $(\mathrm{K}), \mathrm{T}_{\mathrm{i}}$ adalah suhu awal jagung (K). (Hargono dkk., 2012).

$Q_{2}=m_{a} c_{p a}\left(T_{p}-T_{i}\right)$

Dimana $\mathrm{Q}_{2}$ adalah panas yang digunakan untuk menaikkan suhu air di dalam bahan, $\mathrm{m}_{\mathrm{a}}$ adalah massa air $(\mathrm{kg}), c_{p a}$ adalah panas jenis air $\left(\mathrm{kJ} / \mathrm{kg}^{0} \mathrm{C}\right)$. (Hargono dkk., 2012).

$Q_{3}=m_{w} h_{f g}$ 
Dimana $Q_{3}$ adalah jumlah panas yang digunakan untuk menguapkan air bahan, $\mathrm{m}_{\mathrm{w}}$ adalah masaa air yang diuapkan $(\mathrm{kg}), \mathrm{h}_{\mathrm{fg}}$ adalah panas laten penguapan air $(\mathrm{kJ} / \mathrm{kg})$.

Untuk menghitung debit udara yang masuk ke dalam alat menggunakan rumus sebagai berikut, Ardani dkk. (2013):

$$
\dot{\forall}=U A
$$

Dimana $U$ adalah Kecepatan aliran udara masuk $(\mathrm{m} / \mathrm{s}), \quad A$ adalah luas penampang pengering $\left(\mathrm{m}^{2}\right)$. Untuk menghitung volume udara yang masuk ke dalam alat menggunakan rumus sebagai berikut, Ardani dkk. (2013):

$\mathrm{V}=\dot{\forall} \times \Delta \mathrm{t}$ adalah suhu rata-rata udara keluar pengering $\left({ }^{0} \mathrm{C}\right), V$ adalah volume udara $\left(\mathrm{m}^{3}\right)$.

Efisiensi pengeringan terfluidisasi dapat dihitung dengan rumus sebagai berikut, Ardani dkk. (2013):

$$
\eta=\frac{Q}{q} 100 \%
$$

\section{Kecepatan Minimum Fluidisasi}

Menurut Ardani dkk (2013), yang dimaksud kecepatan minimum fluidisasi (dengan notasi $U_{m f}$ ) adalah kecepatan superfisial fluida minimum dimana fluidisasi mulai terjadi. Persamaan yang digunakan untuk menghitung kecepatan fluidisasi minimum adalah, Ardani dkk. (2013):

$U_{m f}^{2}=\frac{d_{p}}{1,75}-\frac{\left(\rho_{s}-\rho_{g}\right) g}{\rho_{g}} \varepsilon_{m f}$
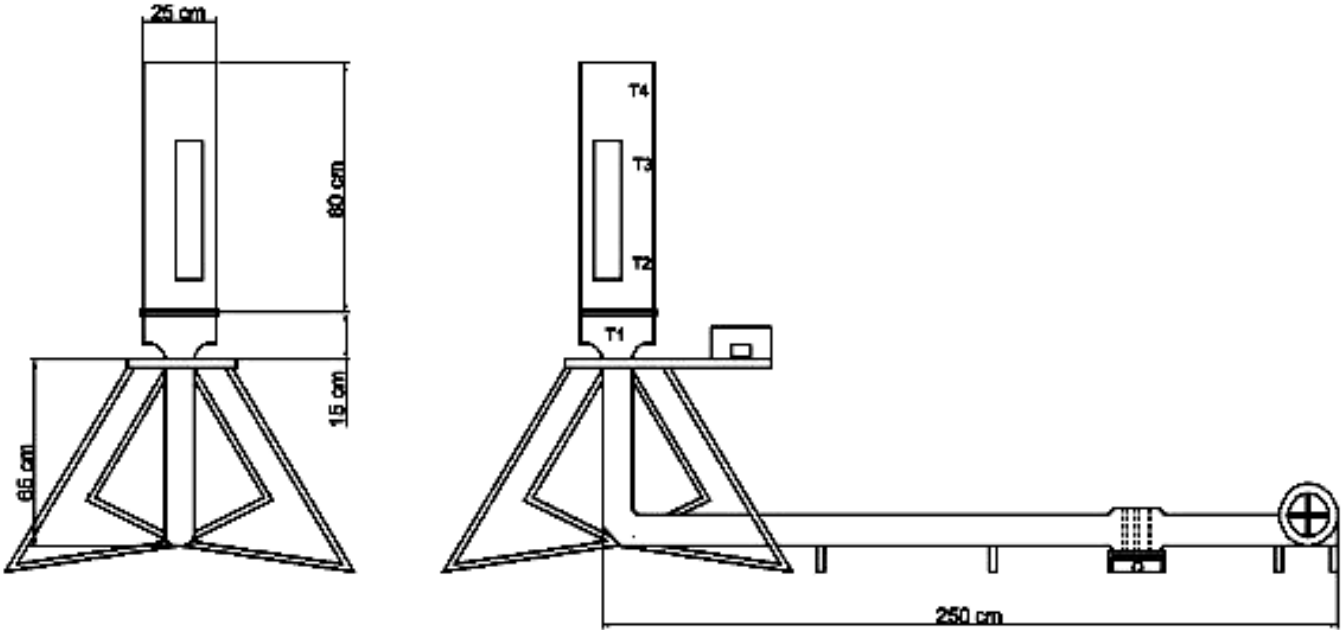

Gambar 1. Alat pengering fluidized bed

Dimana $\Delta$ t adalah ama pengeringan (s). Untuk menentukan banyaknya kalor yang diberikan oleh udara panas pada bahan yang dikeringkan digunakan rumus sebagai berikut, Ardani dkk. (2013):

$q=\rho_{g} V c_{p u}\left(T_{m}-T_{k}\right)$

Dimana $\rho_{\mathrm{g}}$ adalah massa jenis udara $\left(\mathrm{kg} / \mathrm{m}^{3}\right), \mathrm{c}_{\mathrm{pu}}$ adalah panas jenis udara $\left(\mathrm{kJ} / \mathrm{kg}^{0} \mathrm{C}\right) \mathrm{T}_{\mathrm{m}}$ adalah suhu rata-rata udara masuk pengering $\left({ }^{0} \mathrm{C}\right), T_{k}$
Dimana $d_{p}$ adalah diameter partikel $(m), \rho_{\mathrm{s}}$ adalah masaa jenis partikel $\left(\mathrm{kg} / \mathrm{m}^{3}\right), \rho_{\mathrm{g}}$ adalah massa jenis udara $\left(\mathrm{kg} / \mathrm{m}^{3}\right), \varepsilon_{m f}$ adalah porositas unggun $\left(\mathrm{m}^{3}\right)$. Untuk mencari porositas unggun $\left(\varepsilon_{m f}\right)$ dapat digunakan rumus sebagai berikut, Ardani dkk. (2013):

$\varepsilon_{m f}=\frac{V_{p}-V_{u}}{V_{u}}$ 
Dimana $V_{u}$ adalah volume unggun, $V_{p}$ adalah volume partikel.

\section{METODE PENELITIAN}

Skema alat penelitian ditunjukan pada gambar 1.

\section{Prosedur Penelitian}

Sebelum melakukan pengujian, dilakukan beberapa persiapan yaitu mempersiapkan bahan penelitian yaitu jagung yang telah dipipil dan diayak. Setelah biji jagung diayak, kemudian dilakukan penimbangan sesuai kebutuhan dan diukur kadar air biji jagung. Kadar air biji jagung yang digunakan pada penelitian ini adalah $20 \%$ dengan toleransi $0,5 \%$. Apabila kadar air belum sesuai, dilakukan perlakuan seperti perendaman apabila kadar air belum mencukupi atau penjemuran apabila kadar air melebihi standar yang digunakan untuk penelitian.

Setelah biji jagung sudah siap dan sesuai standar penelitian, dilakukan proses pengeringan pada alat fluidized bed dengan dinyalakan blower dan diatur kecepatan udara yang masuk ke ruang pengering dengan variasi kecepatan udara yang digunakan yaitu $5 \mathrm{~m} / \mathrm{s}, 6 \mathrm{~m} / \mathrm{s}$, dan $7 \mathrm{~m} / \mathrm{s}$. Langkah selanjutnya dinyalakan pemanas pada temperatur konstan yaitu $50^{\circ} \mathrm{C}$ dengan toleransi

$1^{\circ} \mathrm{C}$ dan ditunggu kurang lebih 10 menit sampai temperatur benar-benar konstan. Kemudian dimasukkan biji jagung dengan variasi massa seberat $0,5 \mathrm{~kg}, 1 \mathrm{~kg}$, dan 1,5 kg. Dalam melakukan penelitian ini, dilakukan 3 kali pengulangan pengambilan data pada masingmasing variasi kecepatan udara dan massa bahan yang digunakan.

\section{HASIL DAN PEMBAHASAN}

Setelah dilakukan penelitian pengaruh variasi kecepatan udara dan massa bahan terhadap waktu pengeringan jagung pada alat fluidized bed, didapatkan hasil yang berbedabeda. Hasil penelitian mendapatkan waktu pengeringan yang bervariasi sesuai dengan variasi kecepatan dan variasi massa yang dilakukan. Pada massa bahan yang ringan dengan kecepatan udara yang tinggi didapatkan waktu pengeringan paling cepat jika dibandingkan dengan variasi massa bahan yang berat dengan kecepatan udara rendah.

Gambar 2 menunjukkan trend grafik yang sama pada massa bahan $1 \mathrm{~kg}$, dan $1,5 \mathrm{~kg}$ sehingga kecepatan udara berpengaruh terhadap waktu pengeringan jagung. Pengeringan jagung pada massa yang sama dan temperatur udara pengering yang sama dengan menggunakan kecepatan aliran udara yang bervariasi akan mendapatkan waktu pengeringan yang berbeda. Waktu pengeringan yang cepat didapatkan pada kecepatan udara tinggi, sebaliknya waktu pengeringan yang lama didapatkan pada kecepatan udara rendah. Dalam penelitian ini digunakan variasi kecepatan udara $5 \mathrm{~m} / \mathrm{s}, 6 \mathrm{~m} / \mathrm{s}$, dan $7 \mathrm{~m} / \mathrm{s}$ mendapatkan hasil bahwa pada kecepatan udara $7 \mathrm{~m} / \mathrm{s}$ menghasilkan waktu pengeringan yang cepat dibandingkan pengeringan pada kecepatan udara $5 \mathrm{~m} / \mathrm{s}$ dan 6 $\mathrm{m} / \mathrm{s}$. Sedangkan waktu pengeringan yang lama didapatkan pada kecepatan udara $5 \mathrm{~m} / \mathrm{s}$. Hal ini disebabkan karena pada kecepatan rendah, bahan di dalam ruang pengering tidak terfluidisasi maksimal sehingga kadar air di dalam bahan tidak berpindah dengan cepat ke lingkungan. Ketika penguapan kadar air dari bahan ke lingkungan lambat menyebabkan lama waktu pengeringan menjadi lama. Sedangkan pada kecepatan udara tinggi, bahan di dalam ruang pengering terfluidisasi dengan baik dan tinggi unggun lebih tinggi dibandingkan kecepatan rendah. Pada kondisi tersebut, perpindahan kadar air dari bahan ke udara lebih cepat karena lebih mudah berpindah ke lingkungan sehingga waktu pengeringan semakin cepat.

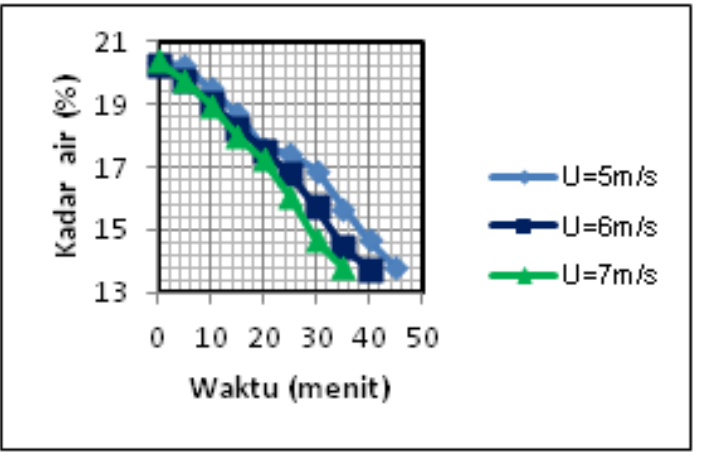

Gambar 2. Hubungan waktu pengeringan dengan kadar air pada massa $0,5 \mathrm{~kg}$

Pada proses pengeringan, air dari bahan basah diuapkan dengan media seperti gas atau udara dengan introduksi panas. Panas yang dibawa udara ini akan memanasi permukaan bahan basah sehingga suhunya naik, dan air akan teruapkan. Oleh karena itu semakin tinggi laju alir udara pengering maka proses pengeringan akan berjalan semakin cepat (Widjanarko dkk, 2012). Hasil penelitian ini juga sesuai dengan pernyataan Mulyono dan Runanda (2013), yang menyatakan bahwa, semakin besar volume udara yang mengalir maka akan semakin besar kemampuannya dalam membawa dan menampung air dari permukaan bahan dan proses pengeringan pun 
menjadi lebih cepat. Sehingga semakin besar laju alir udara, akan mempercepat proses pengeringan. Dan dari hasil penelitian ini bisa disimpulkan bahwa pada kecepatan udara pengering $7 \mathrm{~m} / \mathrm{s}$ mendapatkan waktu paling cepat.

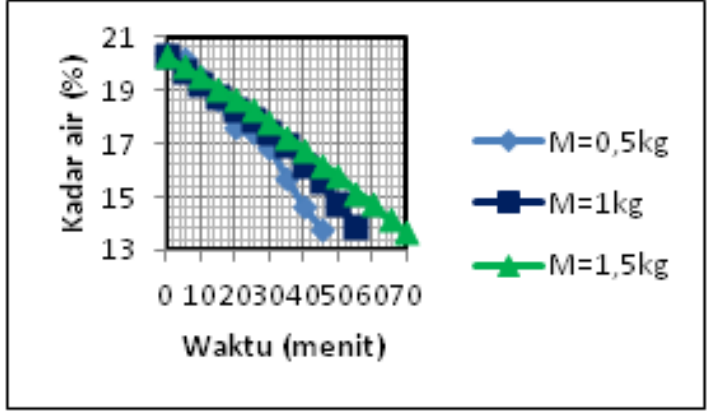

Gambar 3. Hubungan waktu pengeringan dengan kadar air pada kecepatan $5 \mathrm{~m} / \mathrm{s}$

Gambar 3 menghasilkan trend grafik yang sama pada kecepatan udara $6 \mathrm{~m} / \mathrm{s}$ dan $7 \mathrm{~m} / \mathrm{s}$ sehingga pada kecepatan yang sama dengan massa bahan yang dikeringkan berbeda-beda, waktu yang dibutuhkan untuk pengeringan berbeda. Semakin berat massa bahan yang dikeringkan waktu yang dibutuhkan semakin lama. Pada hasil penelitian ini, massa bahan 0,5 $\mathrm{kg}$ memerlukan waktu paling cepat dalam pengeringan dibandingkan dengan massa bahan $1 \mathrm{~kg}$ dan 1,5 kg. Dan waktu pengeringan paling lama didapatkan pada massa bahan $1,5 \mathrm{~kg}$. Hal ini disebabkan karena semakin berat bahan yang dikeringkan membuat partikel bahan di dalam ruang pengering lebih rapat dan tidak terfluidisasi dengan maksimal. Keadaan ini menyebabkan perpindahan kadar air dari dalam bahan ke lingkungan menjadi lambat. Sedangkan pada massa bahan yang ringan, bahan di dalam ruang pengering lebih mudah terfluidisasi dengan baik sehingga tinggi unggun lebih tinggi dibandingkan massa bahan yang berat. Pada keadaan ini, perpindahan kadar air dari bahan ke lingkungan lebih cepat dan waktu pengeringan lebih cepat. Hal ini sesuai dengan pernyataan Suherman dkk (2012), yang menyatakan bahwa semakin banyak berat umpan maka penurunan kandungan uap air di padatan akan semakin landai. Hal ini disebabkan dengan semakin banyak bahan yang akan dikeringkan, maka kebutuhan energi panas untuk mengeringkan akan semakin besar. Sementara itu, udara pengering yang diberikan hampir sama, maka penurunan suhu di unggun akan semakin tinggi. Sehingga untuk massa bahan yang semakin tinggi maka penurunan suhu udara pengering akan lebih besar. Akibatnya laju pengeringan semakin rendah dan penurunan kandungan uap air di padatan akan semakin landai.

\section{KESIMPULAN}

1. Variasi kecepatan udara dan variasi massa bahan berpengaruh terhadap waktu pengeringan jagung.

2. Semakin tinggi kecepatan udara, waktu pengeringan jagung semakin cepat. Dalam penelitian ini, pada kecepatan udara pengering $7 \mathrm{~m} / \mathrm{s}$ menghasilkan waktu pengeringan paling cepat sedangkan kecepatan udara $5 \mathrm{~m} / \mathrm{s}$ mendapatkan waktu pengeringan paling lama.

3. Semakin berat massa bahan yang dikeringkan, waktu pengeringan semakin lama. Dalam penelitian ini, massa jagung 1,5 kg membutuhkan waktu pengeringan paling lama jika dibandingkan dengan massa bahan $0,5 \mathrm{~kg}$.

4. Variasi kecepatan udara dan massa bahan yang membutuhkan waktu pengeringan paling cepat yaitu pada kecepatan udara 7 $\mathrm{m} / \mathrm{s}$ dengan massa bahan $0,5 \mathrm{~kg}$. Waktu yang dibutuhkan untuk mencapai kadar air 13,8\% yaitu 35 menit.

5. Variasi kecepatan udara dan massa bahan yang membutuhkan waktu pengeringan paling lama yaitu pada kecepatan udara $5 \mathrm{~m} / \mathrm{s}$ dengan massa bahan $1,5 \mathrm{~kg}$. Untuk mencapai kadar air 13,7\% membutuhkan waktu pengeringan selama 70 menit.

\section{DAFTAR SIMBOL}

\begin{tabular}{|c|c|}
\hline$\forall$ & : Debit udara \\
\hline$\Delta t$ & : Lama pengeringan $\quad$ (s) \\
\hline$A$ & : Luas penampang pengering $\left(\mathrm{m}^{2}\right)$ \\
\hline$C_{p}$ & : Panas jenis bahan $\quad\left(\mathrm{kJ} / \mathrm{kg}^{\circ} \mathrm{C}\right)$ \\
\hline$C_{p a}$ & : Panas jenis air $\left(\mathrm{kJ} / \mathrm{kg}^{\circ} \mathrm{C}\right)$ \\
\hline pu & : Panas jenis udara $\left(\mathrm{kJ} / \mathrm{kg}^{\circ} \mathrm{C}\right)$ \\
\hline$d_{p}$ & : Diameter partikel (m) \\
\hline $\mathrm{h}_{\mathrm{fg}}$ & : Panas laten penguapan $(\mathrm{kJ} / \mathrm{kg})$ \\
\hline$h_{p}$ & : Tinggi partikel (m) \\
\hline$h_{u}$ & Tinggi unggun (m) \\
\hline$\eta$ & : Efisiensi pengeringan (\%) \\
\hline & $\begin{array}{l}\text { : Banyak kalor yang diberikan pada } \\
\text { bahan }(\mathrm{kJ})\end{array}$ \\
\hline Q & $\begin{array}{l}\text { :Jumlah panas yang digunakan untuk } \\
\text { pengeringan }(\mathrm{kJ})\end{array}$ \\
\hline$Q_{1}$ & : Panas sensibel jagung (kJ) \\
\hline$Q_{2}$ & : Panas sensibel air (kJ) \\
\hline$Q_{3}$ & : Panas laten penguapan air \\
\hline$T_{i}$ & : Suhu awal jagung $\left({ }^{\circ} \mathrm{C}\right)$ \\
\hline$T_{k}$ & : Suhu udara keluar pengering $\left({ }^{\circ} \mathrm{C}\right)$ \\
\hline$T_{m}$ & : Suhu udara masuk pengering $\left({ }^{\circ} \mathrm{C}\right)$ \\
\hline & : Suhu akhir jagung $\left({ }^{\circ} \mathrm{C}\right)$ \\
\hline
\end{tabular}




$$
\begin{array}{ll}
U & : \text { Kecepatan aliran udara }(\mathrm{m} / \mathrm{s}) \\
U_{m f} & : \text { Fluidisasi minimum }(\mathrm{m} / \mathrm{s}) \\
V & : \text { Volume udara }\left(\mathrm{m}^{3}\right) \\
\mathrm{mf} & : \text { Porositas unggun }\left(\mathrm{m}^{3}\right) \\
\mathrm{g} & : \text { Massa jenis udara }\left(\mathrm{kg} / \mathrm{m}^{3}\right) \\
\mathrm{s} & : \text { Massa jenis partikel }\left(\mathrm{kg} / \mathrm{m}^{3}\right)
\end{array}
$$

\section{DAFTAR PUSTAKA}

Ardani R.K., Pradana R.N., Nurtono T., Winardi S., 2013, Review pengaruh hidrodinamika pada fluidized bed dryer, Jurnal Teknik Pomits, vol. 2, No. 1, p. 2.

Daulay S.B., 2005, Pengeringan padi (metode dan peralatan), Jurusan Teknologi Pertanian Fakultas Pertanian Universitas Sumatera Utara.

Hargono, Djaeni M., Buchori L., 2012 , Karakterisasi proses pengeringan jagung dengan metode mixed-adsorption drying menggunakan zeolite pada unggun terfluidisasi, Reaktor, Vol. 14, p. 33-38.

Hasibuan R., 2005, Proses pengeringan, Program Studi Teknik Kimia Fakultas Teknik Universitas Sumatera Utara.

Mahadi, 2007, Model sistem dan analisa pengering produk makanan, USU Repository, Universitas Sumatera Utara.

Mulyono D., Runanda J.C., 2013, Pengeringan gabah menggunakan zeolit $3 a$ pada alat unggun terfluidisasi, Jurnal Teknologi Kimia dan Industri, vol. 2, No. 2, p. 40-45.

Suherman, Purbasari A., Aulia M.P., 2012, Pengaruh suhu udara dan berat sampel pada pengeringan tapioka menggunakan pengering unggun terfluidakan, Jurusan Teknik Kimia Fakultas Teknik Universitas Diponegoro, Semarang.

Tanggasari D., 2014, Sifat teknik dan karakteristik pengeringan biji jagung (zea mays I.) pada alat pengering fluidized beds, Fakultas Teknologi Pangan Dan Agroindustri Universitas Mataram, Mataram.

Taufiq M., 2004, Pengaruh temperatur terhadap laju pengeringan jagung pada pengering konvensional dan fluidized bed, Fakultas Teknik Universitas Sebelas Maret, Surakarta.

Widayati, 2010, Fenomena dan kecepatan minimum $\left(u_{m f}\right)$ fluidisasi, Eksergi, Vol 10, No. 2, p. 42-46.

Widjanarko A., Ridwan, Djaeni M., Ratnawati, 2012, Penggunaan zeolit sintetis dalam pengeringan gabah dengan proses fluidisasi indirect contact, Jurnal Teknologi Kimia dan Industri, vol. 2, No. 2, p. 103110.
Yahya M., 2015, Kajian karakteristik pengering fluidisasi terintegrasi dengan tungku biomassa untuk pengeringan padi, Jurnal Teknik Mesin, Vol. 5, No. 2, p. 65-71. 